\title{
Temporal patterns of suicide and circulatory system disease-related mortality are inversely correlated in several countries
}

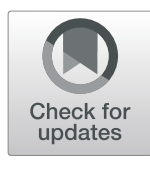

\author{
Marc J. Kaufman ${ }^{1 *}$ and Garrett M. Fitzmaurice ${ }^{2}$
}

\begin{abstract}
Background: Nearly 800,000 suicides occur worldwide annually and suicide rates are increasing faster than population growth. Unfortunately, the pathophysiology of suicide remains poorly understood, which has hindered suicide prevention efforts. However, mechanistic clues may be found by studying effects of seasonality on suicide and other mortality causes. Suicides tend to peak in spring-summer periods and nadir in fall-winter periods while circulatory system disease-related mortality tends to exhibit the opposite temporal trends. This study aimed to determine for the first time whether monthly temporal cross-correlations exist between suicide and circulatory system disease-related mortality at the population level. If so and if common biological factors moderate risks for both mortality types, such factors may be discoverable and utilized to improve suicide prevention.

Methods: We conducted time series analyses of monthly mortality data from northern (England and Wales, South Korea, United States) and southern (Australia, Brazil) hemisphere countries during the period 2009-2018 ( $N=41.8$ million all-cause mortality cases). We used a Poisson regression variant of the standard cosinor model to determine peak months of mortality. We also estimated cross-correlations between monthly mortality counts from suicide and from circulatory system diseases.
\end{abstract}

Results: Suicide and circulatory disease-related mortality temporal patterns were negatively correlated in Australia $(-0.32)$, Brazil $(-0.57)$, South Korea $(-0.32)$, and in the United States $(-0.66)$, but no temporal correlation was discernable in England and Wales.

Conclusions: The negative temporal cross-correlations between these mortality types we found in 4 of 5 countries studied suggest that seasonal factors broadly and inversely moderate risks for circulatory disease-related mortality and suicide, but not in all regions, indicating that the effect is not uniform. Since the seasonal factors of temperature and light exert opposite effects on suicide and circulatory disease-related mortality in several countries, we propose that physiologically-adaptive circulatory system responses to heat and light may increase risk for suicide and should be studied to determine whether they affect suicide risk. For example, heat and light increase production and release of the bioactive gas nitric oxide and reduce circulatory system disease by relaxing blood vessel tone, while elevated nitric oxide levels are associated with suicidal behavior, inverse effects that parallel the inverse temporal mortality patterns we detected.

Keywords: Suicide, Season, Temperature, Thermoregulation, Light

\footnotetext{
* Correspondence: Kaufman@mclean.harvard.edu

'Department of Psychiatry, Harvard Medical School, McLean Imaging Center,

McLean Hospital, 115 Mill St, Belmont, MA 02478, USA

Full list of author information is available at the end of the article
}

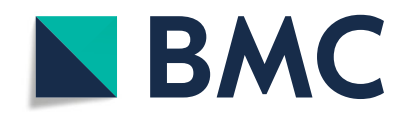

(c) The Author(s). 2021 Open Access This article is licensed under a Creative Commons Attribution 4.0 International License, which permits use, sharing, adaptation, distribution and reproduction in any medium or format, as long as you give appropriate credit to the original author(s) and the source, provide a link to the Creative Commons licence, and indicate if changes were made. The images or other third party material in this article are included in the article's Creative Commons licence, unless indicated otherwise in a credit line to the material. If material is not included in the article's Creative Commons licence and your intended use is not permitted by statutory regulation or exceeds the permitted use, you will need to obtain permission directly from the copyright holder. To view a copy of this licence, visit http://creativecommons.org/licenses/by/4.0/ The Creative Commons Public Domain Dedication waiver (http://creativecommons.org/publicdomain/zero/1.0/) applies to the data made available in this article, unless otherwise stated in a credit line to the data. 


\section{Background}

Nearly 56 million deaths occur each year worldwide including close to 800,000 suicides [1]. While substantial progress has been made to reduce mortality associated with circulatory system diseases and cancers [2, 3], suicide deaths in the United States and worldwide continue to increase $[4,5]$ at rates faster than population growth $[6,7]$, perhaps in part because deaths from other mortality types are declining. Our slow progress at advancing suicide prevention is due in part to our incomplete understanding of the pathophysiology of suicide, which to date has resulted in the development of few treatment options $[8,9]$.

Important clues to better understanding suicide pathophysiology may be found by considering research on seasonal variations in mortality patterns for suicide and for circulatory system diseases, which account for 1.4 and $32 \%$, respectively, of worldwide all-cause mortality [1]. Peaks and nadirs in suicide deaths tend to occur in spring-summer and fall-winter periods, respectively $[10,11]$. Conversely, mortality peaks and nadirs for diseases of the circulatory system tend to occur in fall-winter and spring-summer periods, respectively $[12,13]$. The same seasonal patterns are observed in the northern and southern hemispheres $[10,13]$ meaning that these temporal patterns likely are a consequence of seasonal factors such as temperature or light fluctuations. It has been proposed that physiological mechanisms that drive seasonal fluctuations in circulatory system morbidity and mortality, some of which have been identified, could be exploited to reduce circulatory system disease-related mortality [14]. By extension, physiological mechanisms activated by seasonal factors that moderate suicide risk, some of which could overlap with those driving circulatory system morbidity and mortality, may be discoverable and exploited to better identify those at increased risk for suicide.

Suicide risk increases soon after a major cardiovascular event, presumably as a consequence of increased depression, anxiety, and hopelessness accompanying cardiovascular morbidity $[15,16]$. However, the effects of season were not considered in those studies and to date, a formal evaluation of the degree of temporal correlation between suicide and mortality from diseases of the circulatory system has not been conducted at the population level. Accordingly, we did this by analyzing multi-year mortality data for suicide and for diseases of the circulatory system stratified by month of occurrence. We obtained deidentified data from official death registries of northern hemisphere (England and Wales, South Korea, United States) and southern hemisphere (Australia, Brazil) countries. The dataset included more than 660,000 suicide and 12.2 million circulatory disease-related mortality cases. We conducted cross-correlation time-series analyses on data from each country to determine whether temporal correlations exist between these mortality causes. We hypothesized that temporal patterns of suicide would be negatively correlated with temporal patterns of mortality from diseases of the circulatory system.

\section{Methods \\ Data}

Multiple years of mortality data stratified by month of occurrence were obtained from official death registries in Australia [17], Brazil [18], South Korea [19], the United Kingdom [20], and the United States [21]. Data were extracted for mortality cases resulting from suicide (Intentional self-harm, ICD-10 codes X60-84), from diseases of the circulatory system (ICD-10 codes I00-I99), for all-cause mortality, and were stratified by sex. Other potentially-relevant demographics including socioeconomic, psychiatric, and medical status are not available in these databases and thus are not considered in this analysis. Data demographics are shown in Table 1.

\section{Statistical analysis}

First, we considered within-country seasonality of circulatory disease-related and suicide mortality counts separately. Second, we considered within-country cross-correlation between these two mortality types over time. Parameters of seasonality within countries were estimated using a Poisson regression variant of the standard cosinor model. The cosinor regression

Table 1 Mortality sample cases, sex ratios, and proportions of all-cause mortality

\begin{tabular}{|c|c|c|c|}
\hline Country & All-cause $\mathrm{N} ;\left(\%{ }^{\lambda} / \% q\right)$ & $\begin{array}{l}\text { Circulatory Disorders } \mathrm{N} ;(\% \AA / \%+) \\
\% \text { All-cause / }{ }^{\lambda}: \text { ratio }\end{array}$ & $\begin{array}{l}\text { Suicide } \mathbf{N} ;(\% \delta / \% \text { ) } \\
\% \text { All-cause } / \delta:+ \text { ratio }\end{array}$ \\
\hline Australia ${ }^{a}$ & $1,360,772 ;(51.3 / 48.7)$ & 404,$082 ;(48.3 / 51.7) 29.7 / 0.93$ & 24,$590 ;(75.4 / 24.6) 1.81 / 3.06$ \\
\hline Brazil $^{b}$ & $11,129,455 ;(56.4 / 43.5)$ & $3,103,220 ;(52.4 / 47.6) 27.9 / 1.10$ & 98,646; (78.6/21.3) 0.89 / 3.69 \\
\hline England/Wales ${ }^{c}$ & $3,008,294 ;(48.4 / 51.6)$ & 854,$477 ;(49.9 / 50.1) 28.4 / 1.00$ & 29,$255 ;(76.4 / 23.6) 0.97 / 3.24$ \\
\hline South Korea ${ }^{b}$ & $2,455,047 ;(54.8 / 45.2)$ & 531,$094 ;(47.2 / 52.8) 21.6 / 0.89$ & 126,$633 ;(69.6 / 30.4) 5.16 / 2.29$ \\
\hline United States $^{\mathrm{b}}$ & $23,860,169 ;(50.6 / 49.4)$ & 7,369,083; (50.4/49.6) 30.9 / 1.02 & 386,$536 ;(77.9 / 22.1) 1.62 / 3.52$ \\
\hline Totals (N) & $41,813,737$ & $12,261,956$ & 665,660 \\
\hline
\end{tabular}

Years included: ${ }^{\mathrm{a}} 2009-17 ;{ }^{\mathrm{b}} 2010-18,{ }^{\mathrm{c}} 2010-15$ 
model captures a seasonal pattern using sine and cosine terms that together describe a sinusoidal pattern [22]. In the cosinor model, the number of suicides (or circulatory disease-related mortality cases) for each month was considered to be a Poisson count; specifically, the Poisson regression cosinor model for the mean or expected mortality count is as follows,

$$
\begin{aligned}
\log \left[E\left(M_{t}\right)\right] & =\log \left(\text { days }_{t} / 30\right)+b_{0}+b_{1} \sin (2 \pi t / 12) \\
& +b_{2} \cos (2 \pi t / 12)+b_{3} \text { year }_{t}+b_{4}\left(\text { year }_{t}\right)^{2}, t=1, \ldots, 12 ;
\end{aligned}
$$

where $\mathrm{M}_{\mathrm{t}}$ is the mortality count in month $\mathrm{t}$. The offset term, $\log \left(\right.$ days $\left._{t} / 30\right)$, is included to adjust the counts for the unequal numbers of days in each month (days $\mathrm{f}_{\mathrm{t}}$ ). In addition, a quadratic trend for year of observation was included to allow for possible time trends, increases or decreases in the mortality counts over the years. This model efficiently estimates the month of peak mortality incidence, the relative rate (RR) of mortality type during the month of peak incidence compared with the minimum incidence during the whole year, and a $95 \%$ confidence interval for the RR. Although the counts of suicide and circulatory disease-related mortality are discernibly different, we note that seasonal patterns of change are modelled on a relative, not absolute scale. Finally, the cross-correlation between monthly mortality counts over time was estimated based on the residuals from the regression of mortality counts on a quadratic trend for year of observation, to adjust for trends in mortality over the years.

\section{Results}

Of the five countries sampled, three are in the northern hemisphere (England and Wales, South Korea, and the United States) and two are in the southern hemisphere (Australia and Brazil). Brazil spans the equator but more than $90 \%$ of its population lives in the southern hemisphere [23]. Figure 1 illustrates monthly mortality changes in each

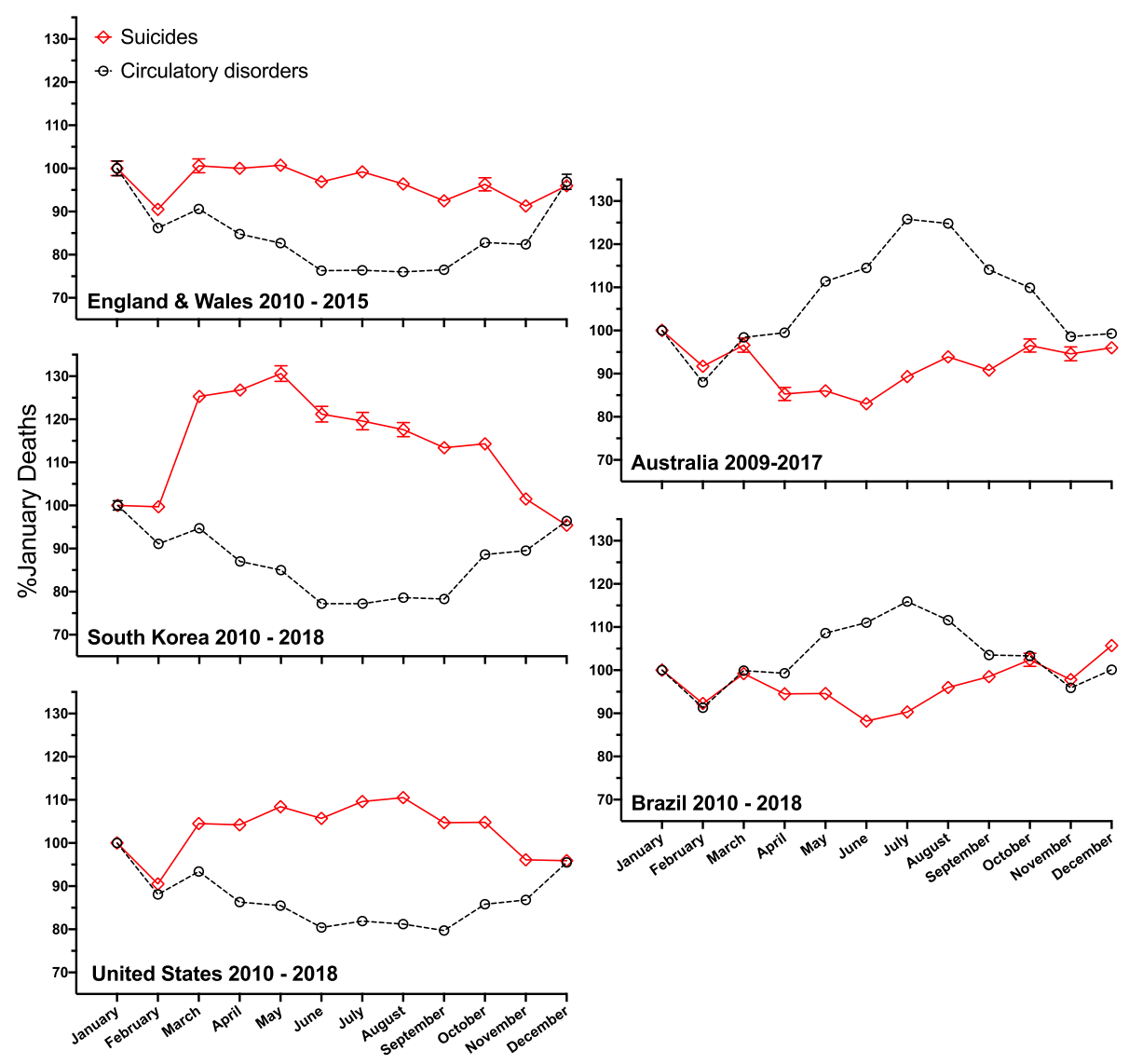

Fig. 1 Monthly suicide and circulatory system disease-related deaths in five countries. Legend: Shown are data for three northern hemisphere (left panels: England \& Wales, South Korea, United States) and two southern hemisphere (right panels: Australia, Brazil) countries as a percentage of January deaths in each year for each cause. Shown are means (averaged over years sampled) \pm standard deviations. These data illustrate that suicide numbers and deaths from circulatory system-related disease increase and decrease, respectively, in spring-summer periods, with inverse patterns for each mortality cause occurring in fall-winter periods. Southern hemisphere temporal patterns are inverted versus northern hemisphere patterns but cross-correlation valences are the same in both hemispheres 
country across all sampled years, expressed as a percent of total January deaths in all years studied, which adjusts for trends in mortality across years. Temporal trends are similar for men and women (data not shown).

For all five countries, there was evidence of seasonality of circulatory disease-related mortality counts, with relative rate estimates varying from 16 to $29 \%$ higher during peak months, and with peak incidence in January in the countries of the northern hemisphere and July in southern hemisphere countries (Table 2). Thus, for circulatory disease-related mortality, we find a remarkably consistent pattern of seasonality, with peak incidence in January in the northern hemisphere and July in the southern hemisphere.

For all five countries, there also was evidence of seasonality of suicide counts, with relative rate estimates varying from 8 to $27 \%$ higher during peak months, and with peak incidence in June or July in two of the three countries of the northern hemisphere and in December in both southern hemisphere countries (Table 2). Interestingly, although there was statistically discernible evidence of seasonality of suicide counts in England and Wales, the relative rate estimate was low, 1.08 (1.04, 1.12), and with peak incidence in the month of April, 23 months earlier than in the USA and South Korea.

Finally, in four countries there was evidence of a negative cross-correlation between monthly suicide and circulatory disease mortality over time, with correlations ranging from -0.32 to -0.66 (Table 2). That is, there was a negative association between the seasonal counts of suicide and circulatory disease-related deaths. However, there was no statistically discernible evidence of cross-association between suicide and circulatory disease mortality in England and Wales.

\section{Discussion}

We report for the first time using population data from multiple countries, that negative temporal cross-correlations exist between mortality resulting from suicide and from circulatory system-related diseases in four of five countries studied. Temporal cross-correlations ranged from -0.32
(Australia and South Korea) to - 0.66 (United States). These findings suggest that seasonal factors broadly and inversely moderate temporal patterns for suicide and circulatory system disease-related mortality to different extents in each country. Our null finding for a temporal cross-correlation in England and Wales highlights that the effects we studied are not uniform in all regions; the null effect probably is due in part to a relatively weak seasonal effect on suicide in these areas (Table 2), consistent with prior studies of this region reporting marginal $[24,25]$ or undetectable [26] effects of season on suicide rates. However, the patterns we detected in 4 of 5 countries in this study are consistent with prior reports of seasonal patterns for circulatory system disease-related mortality [12, 13, 27-29] and for suicide in a number of countries and regions $[10,11,24,25,30-42]$. Although we cannot infer from our data whether cross-correlations exist in other countries, studies of temporal patterns of suicide or circulatory disease-related mortality in Canada, Chile, Finland, Greece, Hungary, Iran, Italy, Norway, and Sweden report apparently inverse temporal patterns for suicide [10, 31, 33, 38-45] and for circulatory disease-related mortality $[13,14,29,46,47]$. Accordingly, it seems possible that the cross-correlations we identified in 4 countries also exist in other countries.

Seasonally-fluctuating factors that could regulate these temporal patterns are temperature and sunlight. Warm temperatures attenuate risk for circulatory system-related morbidity and mortality [28, 48-57] and warm temperatures, especially abnormally warm temperatures during cool months, increase risk, including short-term risk, for suicide [58-70]. Sunlight similarly moderates circulatory disease-related morbidity and mortality [29, 49, 71-73] and suicide risk $[44,58,74-79]$ and may contribute to the temporal cross-correlations we detected. The betweencountry cross-correlation differences we found thus could result from different patterns of seasonal temperature and sunlight changes in each country.

Since temperature and light exert opposite effects on suicide and circulatory disease-related mortality in several

Table 2 Estimates of peak and nadir months, rate ratios, and temporal cross-correlation coefficients between mortality types

\begin{tabular}{|c|c|c|c|c|c|c|c|}
\hline \multirow[b]{2}{*}{ Country } & \multicolumn{3}{|c|}{ Circulatory disease-related } & \multicolumn{3}{|c|}{ Suicide } & \multirow[b]{2}{*}{ Correl. $(95 \% \mathrm{Cl})$} \\
\hline & Peak & Nadir & RR $(95 \% \mathrm{Cl})$ & Peak & Nadir & RR $(95 \% \mathrm{Cl})$ & \\
\hline Australia & July & Jan. & $1.29(1.26,1.31)$ & Dec. & June & $1.14(1.11,1.18)$ & $-0.32(-0.44,-0.19)$ \\
\hline Brazil & July & Jan. & $1.16(1.14,1.18)$ & Dec. & June & $1.12(1.10,1.15)$ & $-0.57(-0.71,-0.38)$ \\
\hline England \& Wales & Jan. & July & $1.29(1.24,1.33)$ & April & Oct. & $1.08(1.04,1.12)$ & $0.14(-0.12,0.38)$ \\
\hline South Korea & Jan. & July & $1.29(1.26,1.32)$ & June & Dec. & $1.27(1.21,1.33)$ & $-0.32(-0.42,-0.20)$ \\
\hline United States & Jan. & July & $1.22(1.20,1.23)$ & July & Jan. & $1.13(1.11,1.14)$ & $-0.66(-0.75,-0.56)$ \\
\hline
\end{tabular}

Legend: Jan. January, Oct. October, Dec. December; RR Rate ratio comparing the relative mortality rate at the peak month to the mortality rate at the nadir month Correl. Cross-correlation between monthly suicide and circulatory system disease-related mortality over time. Note: All analyses have been adjusted to account for the uneven number of days in the month, so that monthly mortality rates have been scaled to an average month of length of 30 -days 
countries, it is plausible that physiologically-adaptive circulatory system responses to heat and light, such as production and release of the bioactive gas nitric oxide (NO), could mediate seasonal effects of heat and light on suicide risk. NO is released as part of thermoregulation, an adaptive process that tightly regulates body heat to prevent heat stress, which can be fatal [80]. Sunlight and artificial light also increase systemic NO levels [72, 81-87] while decreasing blood pressure and vascular resistance $[71,72,82,85,87]$. Because high NO and NO-metabolite levels are found in people with histories of suicide attempts [88-90], heat and/or light-induced NO increases could increase risk for suicide. Further, NO-related genes are associated with risk for suicidal behavior [91-94] and with phenotypes relevant to suicide including general psychological distress [95] and depression induced by economic or psychosocial stressors [96]. Additionally, Liu et al. [72] modeled effects of seasonal differences in ultraviolet A (UVA) light, which account for nearly $80 \%$ of broadband light-induced NO release from skin, and projected greater light-induced NO release after June-like versus after December-like exposures. Moreover, nitric oxide synthase gene expression fluctuates seasonally [97] as do systemic NO metabolite levels, which are highest in summer and lowest in winter months [98]. Thus, although it is speculative at this point to suggest that NO changes play a role in moderating the effects of season on suicide, evidence from several different sources support this possibility.

Better access to air conditioning and heating systems could blunt some of the seasonal temperature extremes that help drive both mortality types, which could contribute to general declines in these mortality types over time [1, 4]. Psychological stressors including socioeconomic stress, which can increase risk for suicide [99] also increase exhaled $\mathrm{NO}$ and blood NO-metabolite levels [100-108]. These findings lend further support to the possibility that high NO levels contribute to suicide risk. It is plausible that socioeconomic and other psychological stressors could combine with seasonal heat and light-induced NO increases to more substantially increase NO levels and suicide risk.

\section{Limitations}

We caution that the estimated peak months, as well as the peak-nadir rate ratio estimates, may be sensitive to the cosinor model assumptions. However, we note that the cosinor model was not adopted for estimation of the temporal cross-correlations. Further, the time-series approach used in this study identified temporal associations but does not provide any information on causal paths. Future studies are required to determine whether the temporal cross-correlations we identified can be found in other regions and can be attributed to NO fluctuations. As noted above, demographic data including socioeconomic, medical, and psychiatric status of decedents are not available in the death registries we sampled and thus these potentially-relevant factors were not considered in this study. Also, our method of analyzing data by month and by country, while revealing clear temporal patterns, likely obscures some temporal effects and regional differences that might otherwise emerge with more granular temporal or geographic analyses (e.g., [38]). Yet, the temporal cross-correlations we revealed are based on hundreds of thousands of cases and while it is possible that the findings may ultimately be found to be artefactual, currently available data from this and other studies suggest that this is unlikely.

\section{Conclusions}

We report negative temporal cross-correlations between mortality resulting from circulatory system-related diseases and from suicide in four of five countries studied, supporting the possibility that seasonal factors that protect against circulatory system-related mortality may increase risk for suicide in some, but not all, countries. The field of suicide prevention urgently needs to identify predictors of suicide risk as current methods are considered to be of little prognostic value [109-111]. Accordingly, although a number of other biological factors likely are involved in this complex disorder [94], we propose that physiologically-adaptive circulatory system responses to heat and light, such as NO production, may increase risk for suicide and should be studied to determine its role in suicide risk.

\section{Abbreviations \\ $\mathrm{Cl}$ : Confidence interval; ICD-10: International classification of diseases, tenth revision; NO: Nitric oxide; RR: Relative rate}

\section{Acknowledgments}

We thank Dr. Ana Carolina Coelho Milani and Mr. Raphael Leme for assisting in data collection.

\section{Authors' contributions}

Dr. Kaufman acquired the data and drafted and revised the work. Dr. Fitzmaurice analyzed the data and edited and revised the work. Both authors conceptualized the work, interpreted the data, and approved of the final work version. Both authors had full access to all of the data in the study and take responsibility for the integrity of the data and for the accuracy of the data analysis.

\section{Funding}

This work was supported in part by McLean Hospital and by NIH grants DA041866 and DA042847.

The sponsors had no role in any aspect of the study or in the decision to submit the manuscript for publication.

\section{Availability of data and materials}

Death registry data for Brazil, England and Wales, South Korea, and the United States can be found at the URLs cited in the Reference Section. Death registry data from Australia was obtained in the form of a customized Excel file report that can be provided upon request. 


\section{Declarations}

\section{Ethics approval and consent to participate}

Not applicable to this study, which used deidentified death registry data.

\section{Consent for publication}

Not applicable.

\section{Competing interests}

The authors declare that they have no competing interests.

\section{Author details}

'Department of Psychiatry, Harvard Medical School, McLean Imaging Center, McLean Hospital, 115 Mill St, Belmont, MA 02478, USA. ²Department of Biostatistics and Department of Psychiatry, Harvard Medical School, Laboratory for Psychiatric Biostatistics, McLean Hospital, 115 Mill St, Belmont, MA 02478, USA.

Received: 1 December 2020 Accepted: 8 March 2021

Published online: 16 March 2021

\section{References}

1. GBD 2017 Causes of Death Collaborators. Global, regional, and national agesex-specific mortality for 282 causes of death in 195 countries and territories, 1980-2017: a systematic analysis for the Global Burden of Disease Study 2017. Lancet. 2018;392:1736-88.

2. Mensah GA, Wei GS, Sorlie PD, Fine LJ, Rosenberg Y, Kaufmann PG, et al, Decline in cardiovascular mortality: possible causes and implications. Circ Res. 2017;120:366-80.

3. Siegel RL, Miller KD, Jemal A. Cancer statistics, 2020. CA Cancer J Clin. 2020; 70:7-30.

4. Naghavi M, Global Burden of Disease Self-Harm Collaborators (286). Global, regional, and national burden of suicide mortality 1990 to 2016: systematic analysis for the Global Burden of Disease Study 2016. BMJ. 2019. https://doi. org/10.1136/bmj.kl94.

5. Wang J, Sumner SA, Simon TR, Crosby AE, Annor FB, Gaylor E, et al. Trends in the Incidence and Lethality of Suicidal Acts in the United States, 2006 to 2015. JAMA Psychiatry. 2020;77:684-93.

6. United States Census Bureau, US population data for 2006 and 2015 https://www.census.gov/en.html. Accessed Accessed 28 May 2020.

7. Roser M, Ritchie H, Ortiz-Ospina E. "World Population Growth." OurWorldlnData.org. 2020. https://ourworldindata.org/world-populationgrowth. Accessed 28 May 2020.

8. Baldessarini RJ. Epidemiology of suicide: recent developments. Epidemiol Psychiatr Sci. 2019;29:e71

9. Nugent $A C$, Ballard ED, Park $L T$, Zarate $C A$ Jr. Research on the pathophysiology, treatment, and prevention of suicide: practical and ethical issues. BMC Psychiatry. 2019;19:332.

10. Petridou E, Papadopoulos FC, Frangakis CE, Skalkidou A, Trichopoulos D. A role of sunshine in the triggering of suicide. Epidemiology. 2002;13:106-9.

11. Galvão PVM, Silva HRSE, da Silva CMFP. Temporal distribution of suicide mortality: A systematic review. J Affect Disord. 2018;228:132-42.

12. Phillips DP, Jarvinen JR, Abramson IS, Phillips RR. Cardiac mortality is higher around Christmas and New Year's than at any other time: the holidays as a risk factor for death. Circulation. 2004;1 10:3781-8.

13. Marti-Soler H, Gonseth S, Gubelmann C, Stringhini S, Bovet P, Chen P-C, et al. Seasonal variation of overall and cardiovascular mortality: a study in 19 countries from different geographic locations. PLoS One. 2014:9:e113500

14. Stewart S, Keates AK, Redfern A, McMurray JJV. Seasonal variations in cardiovascular disease. Nat Rev Cardiol. 2017:14:654-64.

15. Placido A, Sposito AC. Association between suicide and cardiovascular disease: time series of 27 years. Int J Cardiol. 2009;135:261-2.

16. Larsen KK, Agerbo E, Christensen B, Søndergaard J, Vestergaard M. Myocardial infarction and risk of suicide: a population-based case-control study. Circulation. 2010:122:2388-93.

17. Australian Bureau of Statistics (ABS), Selected Mortality Causes 2000-2018, customized report. 2019

18. Ministry of Health, Brazil, Portal of health; TABNET Vital Statistics 1996-2018. Accessed at http://www2.datasus.gov.br/DATASUS/index.php?area $=02$ 05\&id=6937 on June 18, 2020.
19. Korean Statistical Information Service (KOCIS), http://kosis.kr/eng/search/sea rchList.do. Accessed June 11, 2020

20. Office of National Statistics, United Kingdom, Accessed at https://www.ons. gov.uk/peoplepopulationandcommunity/birthsdeathsandmarriages/deaths/a dhocs/112000deathsfromdiseasesofthecardiovascularsystemandischa emicheartdiseasemalesandfemalesbyageandmonthofoccurrenceenglanda ndwalesdeathsoccurringin2010to2018; https://www.ons.gov.uk/ peoplepopulationandcommunity/birthsdeathsandmarriages/deaths/adhocs/ 007536numberofsuicidesbymonthofoccurrenceagesexandregionenglanda ndwales1981to2015; https:/www.ons.gov.uk/peoplepopulationa ndcommunity/birthsdeathsandmarriages/deaths/adhocs/0094 07numberofdeathsbysexandoutputareaenglandandwales2001 to2017, on June 21-23, 2020.

21. Centers for Disease Control and Prevention, National Center for Health Statistics. Underlying Cause of Death 1999-2018 on CDC WONDER Online Database, released in 2020. Data are from the Multiple Cause of Death Files, 1999-2018, as compiled from data provided by the 57 vital statistics jurisdictions through the Vital Statistics Cooperative Program. http://wonder. cdc.gov/ucd-icd10.html. Accessed June 21, 2020

22. Barnett AG, Dobson AJ. Analysing Seasonal Health Data. Berlin, Germany: Springer-Verlag; 2010.

23. Leocadio-Miguel MA, Louzada FM, Duarte LL, Areas RP, Alam M, Freire MV, et al. Latitudinal cline of chronotype. Sci Rep. 2017;7:5437.

24. Yip PS, Chao A, Chiu CW. Seasonal variation in suicides: diminished or vanished. Experience from England and Wales, 1982-1996. Br J Psychiatry. 2000;177:366-9.

25. Cavanagh B, Ibrahim S, Roscoe A, Bickley H, While D, Windfuhr K, et al. The timing of general population and patient suicide in England, 1997-2012. J Affect Disord. 2016;197:175-81

26. Page LA, Hajat $S$, Kovats RS. Relationship between daily suicide counts and temperature in England and Wales. Br J Psychiatry. 2007;191:106-12.

27. Ikefuti PV, Barrozo LV, Braga ALF. Mean air temperature as a risk factor for stroke mortality in São Paulo. Brazil. Int J Biometeorol. 2018;62:1535-42.

28. Guo W, Du M, Sun D, Zhao N, Hao Z, Wu R, et al. The effect characteristics of temperature on stroke mortality in Inner Mongolia and globally. Int J Biometeorol. 2019:63:159-66.

29. Harvey NC, Lorentzon M, Kanis JA, Mc Closkey E, Johansson H. Incidence of myocardial infarction and associated mortality varies by latitude and season: findings from a Swedish Registry Study. J Public Health (Oxford). 2019. https://doi.org/10.1093/scan/fdz131.

30. Morselli H. Suicide : an essay on comparative moral statistics, revised and abridged English version. New York: D. Appleton and Company; 1882.

31. Retamal P, Humphreys D. Occurrence of suicide and seasonal variation. Rev Baiana Saúde Pública. 1998:32:408-12

32. Bando DH, Volpe FM. Seasonal variation of suicide in the city of São Paulo, Brazil, 1996-2010. Crisis. 2014;35:5-9.

33. White RA, Azrael D, Papadopoulos FC, Lambert GW, Miller M. Does suicide have a stronger association with seasonality than sunlight? BMJ Open. 2015; 5:e007403.

34. Plemmons G, Hall M, Doupnik S, Gay J, Brown C, Browning W, et al. Hospitalization for suicide ideation or attempt: 2008-2015. Pediatrics. 2018: 141:e20172426.

35. Moreno-Küstner B, Del Campo-Ávila J, Ruíz-lbáñez A, Martínez-García Al Castro-Zamudio S, Ramos-Jiménez G, et al. Epidemiology of Suicidal Behavior in Malaga (Spain): An Approach From the Prehospital Emergency Service. Front Psychiatry. 2019;10:111

36. Yang $C$, Yip PSF, Cha ES, Zhang Y. Seasonal changes in suicide in South Korea, 1991 to 2015. PLoS One. 2019:14:e0219048.

37. Su MK, Chan PY, Hoffman RS. The seasonality of suicide attempts: a single poison control center perspective. Clin Toxicol. 2020:58:1034-41.

38. Yu J, Yang D, Kim Y, Hashizume M, Gasparrini A, Armstrong B, et al. Seasonality of suicide: a multi-country multi-community observational study. Epidemiol Psychiatr Sci. 2020;29:e163

39. Marion SA, Agbayewa MO, Wiggins S. The effect of season and weather on suicide rates in the elderly in British Columbia. Can J Public Health. 1999;90: $418-22$

40. Heerlein A, Valeria C, Medina B. Seasonal variation in suicidal deaths in Chile: its relationship to latitude. Psychopathology. 2006:39:75-9.

41. Preti A, Lentini G, Maugeri M. Global warming possibly linked to an enhanced risk of suicide: data from Italy, 1974-2003. J Affect Disord. 2007: 102:19-25. 
42. Holopainen J, Helama S, Björkenstam C, Partonen T. Variation and seasonal patterns of suicide mortality in Finland and Sweden since the 1750s. Environ Health Prev Med. 2013;18:494-501.

43. Zeppegno P, Gramaglia C, Castello LM, Bert F, Gualano MR, Ressico F, et al. Suicide attempts and emergency room psychiatric consultation. BMC Psychiatry. 2015;15:13.

44. Seregi B, Kapitány B, Maróti-Agóts Á, Rihmer Z, Gonda X, Döme P. Weak associations between the daily number of suicide cases and amount of daily sunlight. Prog Neuropsychopharmacol Biol Psychiatry. 2017;73:41-8.

45. Rostami M, Jalilian A, Poorolajal J, Mahaki B. Time series analysis of monthly suicide rates in west of iran, 2006-2013. Int J Prev Med. 2019;10:78.

46. Analitis A, Katsouyanni K, Biggeri A, Baccini M, Forsberg B, Bisanti L, et al. Effects of cold weather on mortality: results from 15 European cities within the PHEWE project. Am J Epidemiol. 2008;168:1397-408.

47. Virág K, Nyári TA. Annual and seasonal trends in mortality rates from cardiovascular diseases in Hungary between 1984 and 2013. Cent Eur J Public Health. 2018;26:124-31.

48. Auliciems A, Skinner JL. Cardiovascular deaths and temperature in subtropical Brisbane. Int J Biometeorol. 1989;33:215-21.

49. Capon A, Demeurisse G, Zheng L. Seasonal variation of cerebral hemorrhage in 236 consecutive cases in Brussels. Stroke. 1992;23:24-7.

50. Danet S, Richard F, Montaye M, Beauchant S, Lemaire B, Graux C, et al. Unhealthy effects of atmospheric temperature and pressure on the occurrence of myocardial infarction and coronary deaths. A 10-year survey: the Lille-World Health Organization MONICA project (Monitoring trends and determinants in cardiovascular disease). Circulation. 1999;100:E1-7.

51. Goggins WB, Chan EYY, Yang C-Y. Weather, pollution, and acute myocardial infarction in Hong Kong and Taiwan. Int J Cardiol. 2013;168:243-9.

52. Tanigawa-Sugihara K, Iwami T, Nishiyama C, Kitamura T, Goto M, Ando M, et al. Association between atmospheric conditions and occurrence of outof-hospital cardiac arrest- 10-year population-based survey in Osaka. Circ J. 2013;77:2073-8.

53. Giang PN, Van Dung D, Bao Giang K, Van Vinhc H, Rocklöv J. The effect of temperature on cardiovascular disease hospital admissions among elderly people in Thai Nguyen Province, Vietnam. Glob Health Action. 2014;7:23649.

54. Lee S, Lee E, Park MS, Kwon BY, Kim H, Jung DH, et al. Short-term effect of temperature on daily emergency visits for acute myocardial infarction with threshold temperatures. PLoS One. 2014;9:e94070.

55. Wang Y-C, Lin Y-K. Association between temperature and emergency room visits for cardiorespiratory diseases, metabolic syndrome-related diseases, and accidents in metropolitan Taipei. PLoS One. 2014;9:e99599.

56. Phung D, Thai PK, Guo Y, Morawska L, Rutherford S, Chu C. Ambient temperature and risk of cardiovascular hospitalization: An updated systematic review and meta-analysis. Sci Total Environ. 2016;550:1084-102.

57. Bhaskaran K, Hajat S, Haines A, Herrett E, Wilkinson P, Smeeth L. Short term effects of temperature on risk of myocardial infarction in England and Wales: time series regression analysis of the Myocardial Ischaemia National Audit Project (MINAP) registry. BMJ. 2010;341:C3823.

58. Maes M, De Meyer F, Thompson P, Peeters D, Cosyns P. Synchronized annual rhythms in violent suicide rate, ambient temperature and the lightdark span. Acta Psychiatr Scand 1994:90:391-396.

59. Deisenhammer EA, Kemmler G, Parson P. Association of meteorological factors with suicide. Acta Psychiatr Scand. 2003;108:455-9.

60. Volpe FM, Tavares A, Del Porto JA. Seasonality of three dimensions of mania: psychosis, aggression and suicidality. J Affect Disord. 2008;108:95-100.

61. Tsai J-F, Cho W. Temperature change dominates the suicidal seasonality in Taiwan: a time-series analysis. J Affect Disord. 2012;136:412-8.

62. Qi X, Hu W, Page A, Tong S. Associations between climate variability, unemployment and suicide in Australia: a multicity study. BMC Psychiatry. 2015;15:114

63. Kim Y, Kim H, Honda Y, Guo YL, Chen B-Y, Woo J-M, et al. Suicide and Ambient Temperature in East Asian Countries: A Time-Stratified CaseCrossover Analysis. Environ Health Perspect. 2016;124:75-80.

64. Carleton TA. Crop-damaging temperatures increase suicide rates in India. Proc Natl Acad Sci U S A. 2017;114:8746-51.

65. Dumenčić B, Rajc J, Marjanović K, Požgain I, Pavoković D. Impact of Meteorological Factors on Suicide Attempts and Completed Suicides in Croatia, Osijek-Baranja County. Psychiatr Danub. 2019;31:405-12.

66. Gao J, Cheng Q, Duan J, Xu Z, Bai L, Zhang Y, et al. Ambient temperature, sunlight duration, and suicide: A systematic review and meta-analysis. Sci Total Environ. 2019;646:1021-9.
67. Burke M, González F, Baylis P, Heft-Neal S, Baysan C, Basu S, et al. Higher temperatures increase suicide rates in the United States and Mexico. Nat Clim Chang. 2018;8:723-9.

68. Kalkstein AJ, Belorid M, Dixon PG, Kim KR, Bremer KA. Seasonal variations in temperature-suicide associations across South Korea. Wea Climate Soc. 2019:11:731-9.

69. Schneider A, Hampel R, Ladwig K-H, Baumert J, Lukaschek K, Peters A, et al. Impact of meteorological parameters on suicide mortality rates: A casecrossover analysis in Southern Germany (1990-2006). Sci Total Environ. 2020; 707:136053.

70. Yarza S, Vodonos A, Hassan L, Shalev H, Novack V, Novack L. Suicide behavior and meteorological characteristics in hot and arid climate. Environ Res. 2020;184:109314.

71. Weller RB, Wang Y, He J, Maddux FW, Usvyat L, Zhang H, et al. Does incident solar ultraviolet radiation lower blood pressure? J Am Heart Assoc. 2020;9:e013837

72. Liu D, Fernandez BO, Hamilton A, Lang NN, Gallagher JMC, Newby DE, et al. UVA irradiation of human skin vasodilates arterial vasculature and lowers blood pressure independently of nitric oxide synthase. J Invest Dermatol. 2014;134:1839-46.

73. Mackay DF, Clemens TL, Hastie CE, Cherrie MPC, Dibben C, Pell JP. UVA and seasonal patterning of 56370 myocardial infarctions across Scotland, 20002011. J Am Heart Assoc. 2019;8:e012551.

74. Papadopoulos FC, Frangakis CE, Skalkidou A, Petridou E, Stevens RG, Trichopoulos D. Exploring lag and duration effect of sunshine in triggering suicide. J Affect Disord. 2005;88:287-97.

75. Vyssoki B, Kapusta ND, Praschak-Rieder N, Dorffner G, Willeit M. Direct effect of sunshine on suicide. JAMA Psychiatry. 2014;71:1231-7.

76. Makris GD, Reutfors J, Larsson R, Isacsson G, Ösby U, Ekbom A, et al. Serotonergic medication enhances the association between suicide and sunshine. J Affect Disord. 2016;189:276-81.

77. Jee $\mathrm{H}-J$, Cho $\mathrm{C}-\mathrm{H}$, Lee YJ, Choi N, An H, Lee H-J. Solar radiation increases suicide rate after adjusting for other climate factors in South Korea. Acta Psychiatr Scand. 2017;135:219-27.

78. Frutos AM, Sloan CD, Merrill RM. Modeling the effects of atmospheric pressure on suicide rates in the USA using geographically weighted regression. PLoS One. 2018;13:e0206992.

79. Hernández OH, Hernández-Sánchez JA, Flores-Gutiérrez JD. Annual fluctuations of sunlight and suicides in a region South of the Tropic of Cancer. Biol Rhythm Res. 2018:49:405-11.

80. Charkoudian N. Skin blood flow in adult human thermoregulation: how it works, when it does not, and why. Mayo Clin Proc. 2003;78:603-12.

81. Lohr NL, Keszler A, Pratt P, Bienengraber M, Warltier DC, Hogg N. Enhancement of nitric oxide release from nitrosyl hemoglobin and nitrosyl myoglobin by red/near infrared radiation: potential role in cardioprotection. J Mol Cell Cardiol. 2009:47:256-63.

82. Opländer C, Volkmar CM, Paunel-Görgülü A, van Faassen EE, Heiss C, Kelm $\mathrm{M}$, et al. Whole body UVA irradiation lowers systemic blood pressure by release of nitric oxide from intracutaneous photolabile nitric oxide derivates. Circ Res. 2009;105:1031-40.

83. Holliman G, Lowe D, Cohen H, Felton S, Raj K. Ultraviolet Radiation-Induced Production of Nitric Oxide:A multi-cell and multi-donor analysis. Sci Rep. 2017:7:11105.

84. Keszler A, Lindemer B, Hogg N, Weihrauch D, Lohr NL. Wavelengthdependence of vasodilation and $\mathrm{NO}$ release from S-nitrosothiols and dinitrosyl iron complexes by far red/near infrared light. Arch Biochem Biophys. 2018:649:47-52.

85. Stern M, Broja M, Sansone R, Gröne M, Skene SS, Liebmann J, et al. Blue light exposure decreases systolic blood pressure, arterial stiffness, and improves endothelial function in humans. Eur J Prev Cardiol. 2018;25:1875-83.

86. Albers I, Zernickel E, Stern M, Broja M, Busch HL, Heiss C, et al. Blue light $(\lambda=$ $453 \mathrm{~nm}$ ) nitric oxide dependently induces $\beta$-endorphin production of human skin keratinocytes in-vitro and increases systemic $\beta$-endorphin levels in humans in-vivo. Free Radic Biol Med. 2019:145:78-86.

87. Opländer C, Deck A, Volkmar CM, Kirsch M, Liebmann J. Born M, et al. Mechanism and biological relevance of blue-light (420-453nm)-induced nonenzymatic nitric oxide generation from photolabile nitric oxide derivates in human skin in vitro and in vivo. Free Radic Biol Med. 2013;65:1363-77.

88. Kim Y-K, Paik J-W, Lee S-W, Yoon D, Han C, Lee B-H. Increased plasma nitric oxide level associated with suicide attempt in depressive patients. Prog Neuropsychopharmacol Biol Psychiatry. 2006;30:1091-6. 
89. Lee B-H, Lee S-W, Yoon D, Lee H-J, Yang J-C, Shim S-H, et al. Increased plasma nitric oxide metabolites in suicide attempters. Neuropsychobiology. 2006;53:127-32

90. Vargas HO, Nunes SOV, Pizzo de Castro M, Bortolasci CC, Sabbatini Barbosa

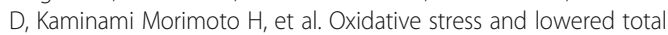
antioxidant status are associated with a history of suicide attempts. J Affect Disord. 2013;150:923-30.

91. Cui H, Supriyanto I, Asano M, Ueno Y, Nagasaki Y, Nishiguchi N, et al. A common polymorphism in the 3'-UTR of the NOS1 gene was associated with completed suicides in Japanese male population. Prog Neuropsychopharmacol Biol Psychiatry. 2010;34:992-6.

92. González-Castro TB, Genis-Mendoza AD, Tovilla-Zárate CA, JuárezRojop IE, López-Narvaez ML, Pérez-Hernández N, et al. Association between polymorphisms of NOS1, NOS2 and NOS3 genes and suicide behavior: a systematic review and meta-analysis. Metab Brain Dis. 2019;34:967-77

93. Oliveira J, Debnath M, Etain B, Bennabi M, Hamdani N, Lajnef $M$, et al. Violent suicidal behaviour in bipolar disorder is associated with nitric oxide synthase 3 gene polymorphism. Acta Psychiatr Scand. 2015;132: 218-25.

94. Zhao Y, Wang L, Wu Y, Lu Z, Zhang S. Genome-wide study of key genes and scoring system as potential noninvasive biomarkers for detection of suicide behavior in major depression disorder. Bioengineered. 2020;11:1189-96.

95. Luciano M, Huffman JE, Arias-Vásquez A, Vinkhuyzen AAE, Middeldorp CM, Giegling I, et al. Genome-wide association uncovers shared genetic effects among personality traits and mood states. Am J Med Genet B Neuropsychiatr Genet. 2012;159B:684-95.

96. Sarginson JE, Deakin JFW, Anderson IM, Downey D, Thomas E, Elliott R, et al. Neuronal nitric oxide synthase (NOS1) polymorphisms interact with financial hardship to affect depression risk. Neuropsychopharmacology. 2014;39: 2857-66.

97. Dopico XC, Evangelou M, Ferreira RC, Guo H, Pekalski ML, Smyth DJ, et al. Widespread seasonal gene expression reveals annual differences in human immunity and physiology. Nat Commun. 2015;6:7000

98. McLaren M, Kirk G, Bolton-Smith C, Belch JJ. Seasonal variation in plasma levels of endothelin-1 and nitric oxide. Int Angiol. 2000;19:351-3.

99. Batty GD, Kivimäki M, Bell S, Gale CR, Shipley M, Whitley E, et al. Psychosocial characteristics as potential predictors of suicide in adults: an overview of the evidence with new results from prospective cohort studies. Transl Psychiatry. 2018;8:22

100. Dietz NM, Rivera JM, Eggener SE, Fix RT, Warner DO, Joyner MJ. Nitric oxide contributes to the rise in forearm blood flow during mental stress in humans. J Physiol. 1994;480(Pt 2):361-8.

101. Cardillo C, Kilcoyne CM, Cannon RO 3rd, Panza JA. Impairment of the nitric oxide-mediated vasodilator response to mental stress in hypertensive but not in hypercholesterolemic patients. J Am Coll Cardiol. 1998:32:1207-13.

102. Cardillo C, Kilcoyne CM, Cannon RO 3rd, Panza JA. Racial differences in nitric oxide-mediated vasodilator response to mental stress in the forearm circulation. Hypertension. 1998:31:1235-9.

103. Pehlivanoğlu B, Balkanci ZD, Ridvanağaoğlu AY, Durmazlar N, Oztürk G, Erbaş $D$, et al. Impact of stress, gender and menstrual cycle on immune system: possible role of nitric oxide. Arch Physiol Biochem. 2001;109:383-7.

104. Chen E, Strunk RC, Bacharier LB, Chan M, Miller GE. Socioeconomic status associated with exhaled nitric oxide responses to acute stress in children with asthma. Brain Behav Immuns. 2010;24:444-50.

105. Ritz T, Ayala ES, Trueba AF, Vance CD, Auchus RJ. Acute stress-induced increases in exhaled nitric oxide in asthma and their association with endogenous cortisol. Am J Respir Crit Care Med. 2011;183:26-30.

106. Reimann M, Hamer M, Malan NT, Schlaich MP, Lambert GW, Ziemssen $T$, et al. Effects of acute and chronic stress on the L-arginine nitric oxide pathway in black and white South Africans: the sympathetic activity and ambulatory blood pressure in Africans study. Psychosom Med. 2013;75:751-8.

107. Ritz T, Trueba AF. Airway nitric oxide and psychological processes in asthma and health: a review. Ann Allergy Asthma Immunol. 2014;112:302-8.

108. Khan SG, Geer A, Fok HW, Shabeeh H, Brett SE, Shah AM, et al. Impaired neuronal nitric oxide synthase-mediated vasodilator responses to mental stress in essential hypertension. Hypertension. 2015;65:903-9.

109. Carter G, Milner A, McGill K, Pirkis J, Kapur N, Spittal MJ. Predicting suicidal behaviours using clinical instruments: systematic review and meta-analysis of positive predictive values for risk scales. Br J Psychiatry. 2017;210:387-95.
110. Quinlivan L, Cooper J, Meehan D, Longson D, Potokar J, Hulme T, et al. Predictive accuracy of risk scales following self-harm: multicentre, prospective cohort study. Br J Psychiatry. 2017;210:429-36.

111. Steeg S, Quinlivan L, Nowland R, Carroll R, Casey D, Clements C, et al. Accuracy of risk scales for predicting repeat self-harm and suicide: a multicentre, population-level cohort study using routine clinical data. BMC Psychiatry. 2018;18:113.

\section{Publisher's Note}

Springer Nature remains neutral with regard to jurisdictional claims in published maps and institutional affiliations.
Ready to submit your research? Choose BMC and benefit from:

- fast, convenient online submission

- thorough peer review by experienced researchers in your field

- rapid publication on acceptance

- support for research data, including large and complex data types

- gold Open Access which fosters wider collaboration and increased citations

- maximum visibility for your research: over $100 \mathrm{M}$ website views per year

At $\mathrm{BMC}$, research is always in progress.

Learn more biomedcentral.com/submissions 